\title{
EGÉSZSÉGTUDATOSSÁG SAJÁTOS VONÁSAI A 11-17 ÉVES MAGYAR FIATALOK VONATKOZÁSÁBAN AZ EZREDFORDULÓT KÖVETŐEN A HBSC KUTATÁS ADATAI ALAPJÁN - SZAKIRODALMI ÁTTEKINTÉS
}

\author{
- ho \\ LITERATURE REVIEW \\ \&a \\ FERENCZI, MILÁN \\ LENTÉNÉ DR. PUSKÁS, ANDREA \\ se \\ Debreceni Egyetem, Sporttudományi Koordinációs Intézet \\ (University of Debrecen, Sport Science Coordination Institute) \\ H-4032 Debrecen, Dóczy József utca \\ e-mail: ferenczim98@gmail.com
}

\section{SPECIFIC FEATURES OF HEALTH AWARENESS FOR 11-17-YEAR-OLD HUNGARIAN STUDENTS AFTER THE MILLENNIUM BASED ON HBSC RESEARCH DATA -}

The aim of this study is to present the health behaviour of 11-17-year-old Hungarian students. In connection with this topic we analyzed international and Hungarian articles based on primer researches and the results of a Hungarian survey as part of an international research, namely „The Health Behaviour in School-aged Children” (HBSC). The aim of the research is to monitor health related habits and health status of 11-17-year-old students, to track temporal and international trends of survey results, and to explore factors influencing health indicators. In this study we present the results of health promoting (nutrition, physical activity) and health compromising behaviours (smoking, alcohol consumption) and their characteristic changes based on five recent surveys $(2002,2006,2010,2014,2018)$. During this study, we made a document analysis based on the previous Hungarian research results. The results showed a prosperous scheme, which predicts a slow but steady positive change, however there is still a long way to go. The biggest problem in the way of life of these children is the lack of conscious behaviour. Most of these children are not aware of the consequences of their lifestyle on their health.

KuLCSSZAVAK: egészségmagatartás, egészséges táplálkozás, serdülőkor, trendek, elemzés, HBSC

JEL-KódOK (JEL CODES): I12

DOI: https://doi.org/10.20494/TM/8/1/3
KEYwORDS: health behaviour, healthy nutrition, adolescence, trends, analysis, HBSC 


\section{BEVEZETÉS - INTRODUCTION}

Ezen szakirodalmi áttekintés megelőző vizsgálatát képezi egy saját kérdőíves felmérésnek, mely során véletlenszerüen kiválasztott nyolc, Hajdú-Bihar megyében múködő általános iskola 500 felső tagozatos diákját kérdeztünk meg az egészséges életmóddal, egészséges táplálkozással és a rendszeres testmozgással kapcsolatosan. Az elvégzett dokumentumelemzés eredményeit és tapasztalatait felhasználva készítettük el a kérdőívet, a vizsgált korosztály táplálkozási és sportolási szokásainak megismerése érdekében.

Magyarországon az elhízás napjainkban már népbetegségnek számít, mely számos káros következménnyel párosul. A Központi Statisztikai Hivatal egészségre és a gyermekek egészségére vonatkozó 2017. évi felmérésének adatai alapján egyértelmúen megállapítható, hogy hazánkban a felnőtt lakosság több mint fele túlsúlyos (KSH, 2018). Sajnos ez az állapot a felnőttek mellett már a kisgyermekeket is érinti. A korai, gyermekkorban vagy serdülőkorban történő elhízás nehezen megállítható és még nehezebben visszafordítható folyamat. A gyermekkori elhízás problémája, illetve növekvő előfordulása az egész világon megfigyelhető. Az Európai Unióban a túlsúlyos vagy elhízott gyermekek száma meghaladja a 12 milliót. A túlsúlyosak száma évente 400 ezerrel, míg a kövér gyerekek száma 85 ezerrel nő. Magyarországon minden negyedik lány és minden ötödik fiú túlsúlyos vagy elhízott. 3-7 éves kor között figyelhető meg az elhízás fellendülése, így a kisgyermekkorban kezdődő elhízás jelentős kockázati tényezőt jelent a felnőttkori elhízás tekintetében (MARTOS, 2012).

Számos hazai és nemzetközi kutatás foglalkozik a rendszeres testmozgás és fizikai aktivitás egészségre gyakorolt jótékony hatásával, valamint az egészséges táplálkozással, a táplálkozási trendek változásával (FÜLÖP és SZAKÁLY, 2008; JÁROMI et al., 2016; GYULAVÁRI et al., 2018; LENTÉNÉ et al., 2018). A serdülőkorú fiatalok egészségi állapotára és egészségmagatartására vonatkozó kutatások eredményeinek ismerete és felhasználása kiemelkedő jelentőséggel bír a hatékony egészségfejlesztő programok kidolgozása és megvalósítása érdekében (HOLCZER és KISS, 2019).
Az egészségtudatosság, az egészséges életmód több komponensből áll. A táplálkozás alapvetően meghatározza és befolyásolja életünket, de hosszú távon az egészségünket is. Fontos a szervezetbe bevitt tápanyagok megfelelő kiválasztása, azaz egészséges élelmiszerek fogyasztásának előtérbe helyezése. Másik fontos komponens a testmozgás, azaz a testünk karbantartása. Továbbá meg kell említeni a káros szenvedélyek mellőzését is, mint fontos komponense az egészséges életmód kialakításának (FALUS, 2015).

A rendszeres, aktív testmozgás az egészséges életmód egyik pillére, azonban ezt az emberek jelentős része ritkán kapcsolja össze. A fizikai aktivitás, a sportolás rendkívül sok kedvező élettani hatással rendelkezik, melyet számos kutatási eredmény alátámaszt (JÁROMI et al., 2016; BÍRÓ et al., 2018). Mindezek ellenére az Európai Bizottság 2017. évi felmérése alapján a magyaroknak csupán $15 \%$-a sportol rendszeresen, hetente legalább egy alkalommal (EUROBAROMETER, 2017). A rendszeres testmozgásnak megelőző hatása van mind gyermekkorban, mind felnőttkorban. Gyermekkorban a fizikai aktivitás jelentős szerepet tölt be a szervezet energiaegyensúlyának fenntartásában és jótékonyan segíti a csontfejlődést is (MILES, 2007). A 11-17 éves korosztály körében a testmozgás és az általa kialakult és megszerzett edzettségi állapot védőhálóként veszi körül a fejlődő szervezetet (JANSSEN és LEBLANC, 2010), csökkenti a krónikus betegségek kialakulásának későbbi kockázatát (MILES, 2007), és segít megelőzni az elhízást továbbá csökkenti a testsúlyt is (ANDERSON és BUTCHER, 2006). A rendszeres fizikai aktivitásnak kiemelkedően jelentős szerepe van a szív- és érrendszeri betegségek kialakulása, az elhízás, a cukorbetegség megjelenése, a magas vérnyomás és a magas koleszterinszint kialakulásának megelőzésében (HÍDVÉGI et al., 2015). Továbbá az aktív fizikai mozgás a lelki egészséget is pozitívan befolyásolja. A sport pozitívan formálja a fiatalok személyiségét, nagymértékben támogatja az egészséges személyiségfejlődést, a testi és a lelki érési folyamatokat, hozzájárul a jó hangulathoz, a jobb lelki állapothoz, azaz az egész szervezetre kedvezően hat (STRONG et al., 2005).

Az egészséges életmód alapvető kiinduló- 
pontja annak, hogy megőrizzük egészségünket, egészségesek maradjunk, de ezért sokat kell tenni. Ez valójában egy életforma, mely bármikor megváltozhat külső hatások nyomására, de az ember által saját belső igényének megfelelően bármikor megváltoztatható (FÜGE, 2015). FALUS (2015) értelmezésében egy ember életmódja minden esetben specifikus, azaz csak rá jellemző, ezáltal meghatározza az ember egyéniségét. Ebből következik, hogy az életmód megváltoztatása - akár jó, akár rossz irányba - is mindig az egyéntől függ. Az életmód objektív és szubjektív meghatározó tényezőket foglal magába. Egyrészt feltételeket és a lehetőségeket (objektív meghatározó tényezők), valamint a szükségleteket és az indítékokat (szubjektív meghatározó tényezők). Az életmód lehetővé teszi az emberek számára, hogy egészségüket megőrizzék, megszilárdítsák és egészségesen éljenek.

Jelen kutatásunk célja, hogy megismerjük és elemezzük a 11-17 éves korosztály egészségét befolyásoló szokásait és szubjektív egészségi állapotát valamint elvégezzük a korábbi felmérések során kapott eredmények időbeli trendjének követését. Szakirodalmi kutatásunk során az elmúlt öt alkalommal végzett HBSC nemzetközi kutatási eredmények (NÉMETH et al., 2019) közül kizárólag csak a Magyarországon elvégzett kutatás során kapott adatokat elemeztük, melyek a magyar serdülőkorú fiatalok egészségmagatartását mutatják be. Továbbá a vizsgált időszakon belül kizárólag azzal az öt kérdéssel foglalkoztunk, melyek valamennyi kérdőívben változatlan formában szerepeltek az általunk kiválasztott időszakban. Így tudtuk elemezni az ezredfordulót követően a fiatalok egészségtudatosságát befolyásoló tényezők változását.

\section{ANYAg ÉS MÓDSZER - MATERIAL AND METHOD}

Jelen cikkben szakirodalmi áttekintést hajtottunk végre, melynek során dokumentumelemzést végeztünk a hazai primer kutatásokon alapuló cikkek, releváns szakirodalmak, kutatási eredmények valamint az „Iskoláskorú gyermekek egészségmagatartása” (Health Behaviour is School-aged Children, HBSC) nemzetközi kutatás adatait elemeztük. Kutatásunk során részletesen elemeztük a HBSC kutatás adatait és eredményeit. A HBSC kutatás az egyik legfontosabb kutatás, mely az iskoláskorú gyerekek egészségmagatartásával foglalkozik. Ez egy nemzetközi kutatás, mely egységes módszertannal negyvennél is több országban zajlik. A kutatást 4 évente ismétlik. A kutatás során nem csak egy területtel foglalkoznak, hanem komplexen mérik fel a gyerekek egészségmagatartását. A kutatás során egyrészt megismerhetjük az egészség szempontjából fontos környezeti tényezőket, továbbá megismerhetjük a gyerekek egészséges életmóddal kapcsolatosan tanúsított magatartásait is (NÉMETH és KÖLTÔ, 2016). A kutatás fóbb célkitűzései: információgyüjtés, nemzetközi adatbank létesítés; az egészséggel, a közérzettel és az életmóddal összefüggést mutató tényezők mind szélesebb körben való feltárása; a résztvevő országok kutatási potenciáljának fejlesztése a nemzetközi kollaboráció segítségével (NÉMETH és KÖLTÖ, 2016).

A HBSC kutatás az egyik legfontosabb kutatás Magyarországon, mely az iskoláskorú gyermekek egészségmagatartásával foglalkozik, továbbá a fiatalok életmódját, testi - lelki egészségét háttértényezőkkel (család, gazdasági helyzet, személyiségjegyek, szülői és tanári bánásmód) is vizsgálja (NÉMETH et al., 2019).

\subsection{Iskoláskorú gyermekek egészség- magatartása - Health Behaviour in School-Aged Children}

A HBSC interdiszciplináris, a WHO-val együttmúködésben zajló nemzetközi kutatás, melyet az 1980-as évek elején négy ország (Norvégia, Finnország, Ausztria és Anglia) kutatói kezdeményezték informális együttmúködésként. A kutatási programban résztvevő országok száma folyamatosan növekszik (NÉMETH és KÖLTŐ, 2016), Magyarország 1985-ben csatlakozott a nemzetközi kutatási programhoz. Ez a kutatás lehetőségeket biztosít arra, hogy felmérje az egészség szempontjából kiemelt szereppel rendelkező, nagyon fontos, meghatározó jelentőségű környezeti tényezők szubjektív megítélését, valamint, hogy teljes körü képet kapjunk a 11, 13, 15 és 17 éves, serdülőkorú magyar fiatalok egészségi állapotáról, egészséget 
befolyásoló magatartásáról, életmódjáról, továbbá a későbbi (felnőttkori) egészségi állapot szempontjából meghatározó magatartások kiindulási pontjairól. Ezek az ismeretek nélkülözhetetlenek a hatékony egészségnevelési és egészségfejlesztő programok, stratégiák kidolgozásához, továbbfejlesztéséhez (NÉMETH és KÖLTŐ, 2016).

\subsection{Minta - Sample}

A nemzetközi kutatási protokollnak megfelelően a mintaválasztás rétegzett mintavételi eljárással készült a kutatást megelőző évben az országos reprezentativitás érdekében. A felmérésben az 5. 7. 9. és 11. évfolyamos tanulók vesznek részt (NÉMETH és KÖLTŐ, 2016).

Az elemzés során öt magyarországi mintát vettünk figyelembe (1. táblázat).

\subsection{Kutatási kérdőív - Research \\ Questionnaire}

A kérdőívek alapvetően olyan kérdéseket tartalmaztak, melyek a vizsgált korosztály egészségmagatartását jól jellemzik. A két felmérés között eltelt négy évben nemzetközi munka keretén belül a kérdőíveket folyamatosan felülvizsgálják, aktualizálják. Vannak a kötelezó kérdések, vannak a választható kérdéscsoportok $\left(^{*}\right)$, melyeket a kötelező kérdésekkel azonos témakörben dolgoznak ki, egy-egy témakör alaposabb megismerése érdekében. A harmadik kérdéscsoportba pedig azok a hazai fejlesztésű kérdések $(* *)$ tartoznak, melyet az adott ország a nemzeti viszonyokat figyelembe véve tesz fel, hogy a hazai igényeknek megfelelően tudjon vizsgálni egy adott témát (NÉMETH et al., 2019). A vizsgált témakörök a 2. táblázatban találhatók meg.

\section{TÁBLÁZAT}

TABLE 1

A HBSC kutatásban résztvevők száma vizsgálati év szerint (The Number of HBSC Research Participants by Test Year)

\begin{tabular}{cccc}
\hline Vizsgálati év (Test year) & Fiúk (fö) (Boys, capita) & $\begin{array}{c}\text { Lányok (fö) (Girls, } \\
\text { capita) }\end{array}$ & $\begin{array}{c}\text { Összesen (fó) (Total, } \\
\text { capita) }\end{array}$ \\
\hline 2002. & 2730 & 3228 & 5958 \\
\hline 2006. & 2815 & 2635 & 5450 \\
\hline 2010. & 4174 & 3922 & 8096 \\
\hline 2014. & 2958 & 3194 & 6153 \\
\hline 2018. & 2949 & 3049 & 6003 \\
\hline
\end{tabular}

Forrás (Source): Saját szerkesztés Németh et al., 2019 adatai alapján (Authors'own compilation based on data of Németh et al., 2019) 
Vizsgált témakörök a hazai kutatásban

(The Topics in Domestic Research)

\begin{tabular}{|c|c|c|c|c|}
\hline $\begin{array}{c}\text { Egészség- } \\
\text { magatartás } \\
\text { (Health } \\
\text { Behavior) }\end{array}$ & $\begin{array}{c}\text { Rizikó- } \\
\text { magatartás } \\
\text { (Risk } \\
\text { Behavior) }\end{array}$ & $\begin{array}{c}\text { Kortárs- } \\
\text { kapcsolatok (Peer } \\
\text { Relationships) }\end{array}$ & $\begin{array}{c}\text { Szubjektív jóllét, } \\
\text { mentális egészség } \\
\text { (Subjective Well-being, } \\
\text { Mental Health) }\end{array}$ & $\begin{array}{c}\text { Pszichoszociális } \\
\text { kontextuális tényezők } \\
\text { (Psychosocial } \\
\text { Contextual Factors) }\end{array}$ \\
\hline $\begin{array}{l}\text { Táplálkozási } \\
\text { szokások (Eating } \\
\text { Habits)** }\end{array}$ & $\begin{array}{l}\text { Dohányzási szo- } \\
\text { kások (Smoking } \\
\text { Habits)* }\end{array}$ & $\begin{array}{l}\text { Kortársbántalmazás } \\
\text { (Peer Abuse) }\end{array}$ & $\begin{array}{l}\text { Szubjektív jóllét } \\
\text { (Subjective Well-being) }\end{array}$ & $\begin{array}{l}\text { Társadalmi-gazdasági } \\
\text { háttér (Social-economic } \\
\text { background) }\end{array}$ \\
\hline $\begin{array}{l}\text { Fogápolás (Dental } \\
\text { Care) }\end{array}$ & $\begin{array}{l}\text { Alkoholfogyasz- } \\
\text { tási szokások } \\
\text { (Drinking } \\
\text { Habits)* }\end{array}$ & Verekedés (Tussle) & $\begin{array}{l}\text { Egészségi állapot (Health } \\
\text { Status) }\end{array}$ & $\begin{array}{l}\text { A családok szocioökonó- } \\
\text { miai helyzete (Socio- } \\
\text { economic situation of } \\
\text { families) }\end{array}$ \\
\hline $\begin{array}{l}\text { Fizikai aktivitás } \\
\text { (Physical } \\
\text { Activity) }\end{array}$ & $\begin{array}{l}\text { Drogfogyasztási } \\
\text { szokások (Drog } \\
\text { Use Habits)** }\end{array}$ & $\begin{array}{l}\text { Kortárskapcsolatok } \\
\text { (Peer Relationships) }\end{array}$ & $\begin{array}{l}\text { Alvási szokások } \\
\text { (Sleep Habits)* }^{*}\end{array}$ & $\begin{array}{l}\text { Családszerkezet (Family } \\
\text { Structure) }\end{array}$ \\
\hline \multirow[t]{2}{*}{$\begin{array}{l}\text { Képernyő-haszná- } \\
\text { lat (Screen Usage) }\end{array}$} & $\begin{array}{l}\text { Sérülések, bal- } \\
\text { esetek (Injuries, } \\
\text { Accidents) }\end{array}$ & $\begin{array}{l}\text { Szexuális magatartás } \\
\text { (Sexual Behavior) }\end{array}$ & $\begin{array}{l}\text { Tápláltsági állapot } \\
\text { (Nutritional Status) }\end{array}$ & $\begin{array}{l}\text { Családi kapcsolatok } \\
\text { (Family } \\
\text { Relationships) }\end{array}$ \\
\hline & & $\begin{array}{l}\text { Romantikus kap- } \\
\text { csolatok (Romantic } \\
\text { Relationships)* }\end{array}$ & $\begin{array}{l}\text { Testkép* és testtömeg-sza- } \\
\text { bályozás (Body Image and } \\
\text { Weight Control) }\end{array}$ & $\begin{array}{l}\text { Az iskola szerepe (The } \\
\text { role of the school) }\end{array}$ \\
\hline
\end{tabular}

Forrás (Source): Saját szerkesztés Németh et al., 2019 adatai alapján (Authors' own compilation based on data of Németh et al., 2019)

\section{EREDMÉNYEK - RESUltS}

A tudományos kutatásunk során az időbeli összehasonlító elemzéshez azokat a kérdéseket választottuk ki a hazai HBSC kutatásból, melyek az általunk vizsgált utolsó öt (2002., 2006., 2010., 2014., 2018.) „Iskoláskorú gyermekek egészségmagatartása” elnevezésủ hazai kutatás valamennyi kérdőívében változatlan formában megjelentek. Elsősorban a serdülőkorú fiatalok egészségmagatartásáról ma Magyarországon a HBSC kutatás adataiból informálódhatunk. Továbbá az ezredfordulót követő több hazai kutatás eredményeit felhasználva az alábbi mutatók változásait vizsgáltuk.
Táplálkozás:

- Napi rendszerességgel gyümölcsöt fogyasztó tanulók aránya.

- Napi rendszerességgel cukortartalmú üdítőitalt fogyasztó tanulók aránya.

Fizikai aktivitás:

- Naponta legalább 60 percet, legalább közepes intenzitással mozgó tanulók aránya. Kockázati magatartás (pszichoaktív szerfogyasztás):

- Minden nap dohányzó tanulók aránya.

- Életükben már legalább két alkalommal lerészegedett tanulók aránya. 


\subsection{Táplálkozás - Nutrition}

A WHO ajánlása szerint a napi zöldség-gyümölcsfogyasztás ajánlott mennyisége 400 gramm (WHO, 2003). Ez naponta két darab almát vagy azzal egyenértékú egyéb gyümölcsöt jelentene. A Központi Statisztikai Hivatal 2016-os kutatása szerint a magyarok fejenként csak napi 262 gramm zöldséget és gyümölcsöt fogyasztanak. (KSH, 2018). BÍRÓ (2018) kutatási eredményei alapján is megfigyelhető ez a kedvezőtlen eredmény, mely szerint a serdülökorú fiatalok gyümölcsfogyasztása jóval alatta van az adott korcsoportú fiatalok számára ajánlott mennyiségnek.

A napi gyakorisággal rendszeresen gyümölcsöt fogyasztó magyar fiatalok számáról a kutatási eredmények adatait vizsgálva (1. ábra) megállapítható, hogy a 2000-es évek elejétől egészen 2014-ig emelkedő tendenciát mutatott, majd ezt követően 2018-ra jelentős visszaesés volt tapasztalható. A 2002-es felmérésben a válaszadók 29,1\%-a (1734fó) fogyasztott minden nap gyümölcsöt, majd ez az arány 2014-re elérte a 32,6\%-ot (2006 fó), ugyanakkor 2018-ban csak a válaszadók 28,8\%-a (1729 fó) mondta azt, hogy minden nap fogyaszt. A nemi különbségeket vizsgálva egyértelműen megállapítható, hogy a lányok több gyümölcsöt fogyasztanak, mint a fiúk (NÉMETH et al., 2019).

A vizsgált időszak eredményei alapján egyértelműen megállapíthatjuk, hogy a serdülőkorú magyar fiataloknak még $1 / 3$-a sem fogyaszt napi rendszerességgel gyümölcsöt. Különösen aggasztó, hogy 2018-ban jelentősen visszaesett a gyümölcsfogyasztók aránya, a vizsgált időszakban a legalacsonyabb volt.

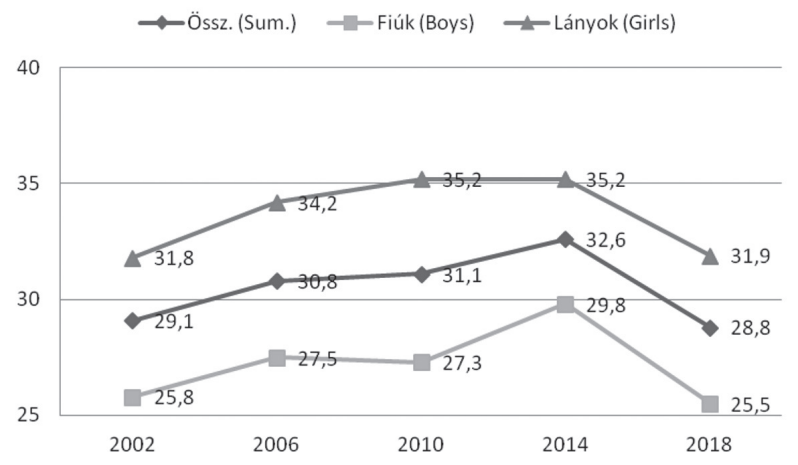

1. ÁBRA 2002

2010

2014

FIG. 1

Napi rendszerességgel gyümölcsöt fogyasztó 11-17 éves magyar fiatalok arányának változása (The Change in the Proportion of 11-17-Year-Old Hungarian Young People Consuming Fruit Daily)

Forrás (Source): Saját szerkesztés Németh et al., 2019 adatai alapján (Authors'own compilation based on data of Németh et al., 2019)

Az alkoholmentes italok (ásványvíz, szénsavas üdítőitalok, gyümölcslevek) fogyasztása Magyarországon 2007-ben érte el a csúcsot, közel 215 liter/fő. Azonban a fogyasztói szokások átalakulásával megváltozott a cukortartalmú üdítőitalok fogyasztása is, egyre inkább háttérbe került és átvette helyét az ásványvíz (LŐRINCZI, 2010).

A napi rendszerességgel cukortartalmú üdítőitalokat fogyasztó fiatalok körében 2006 és 2014 között igen erőteljes csökkenés figyelhető meg, különösen a fiúk vonatkozásában (2. ábra). Míg 2002-ben a válaszadók 32,7\%-a
(1948 fó) fogyasztott rendszeresen cukros üdítőket, 2018-ra ez az arány lecsökkent 25,5\%-ra (1531 fó). Ez az érték bizakodásra adhat okot. A nemi különbségeket vizsgálva egyértelműen megállapítható, hogy a fiúk több cukortartalmú üdítőt isznak, mint a lányok (NÉMETH et al., 2019).

A vizsgált időszakban közel 7\%-kal csökkent azok száma, akik rendszeresen fogyasztanak cukrozott üdítőitalokat, de még így is a fiatalok 1/4-e iszik olyan üdítőket, mely hasznos, a szervezet számára nélkülözhetetlen tápanyaggal nem szolgál, kizárólag energiát biztosít. 


\section{EGÉSZSÉGTUdATOSSÁG SAJÁTOS VONÁSAI A 11-17 ÉVES MAGYAR FIATALOK VONATKOZÁSÁBAN AZ EZREDFORDULÓT KÖVETóEN A HBSC KUTATÁS ADATAI ALAPJÁN - SZAKIRODALMI ÁTTEKINTÉS}

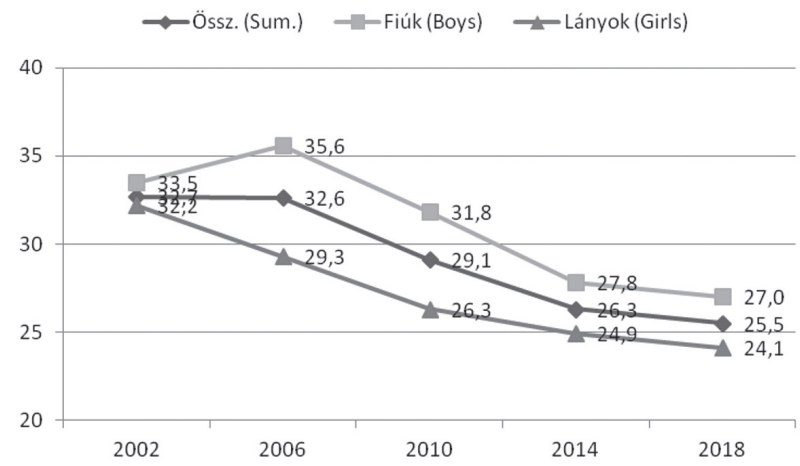

2. ÁBRA

\section{Napi rendszerességgel cukortartalmú üdítőitalokat fogyasztó 11-17 éves magyar fiatalok arányának változása (The Change in the Proportion of 11-17-Year-Old Hungarian Young People Consuming Sugary Soft Drink Daily)}

Forrás (Source): Saját szerkesztés Németh et al., 2019 adatai alapján (Authors' own compilation based on data of Németh et al., 2019)

\subsection{Fizikai aktivitás - Physical Activity}

Az EUROBAROMETER (2017) felméréséból az derül ki, hogy a magyarok közel 1/3-a végez testmozgást kisebb-nagyobb gyakorisággal. A megkérdezettek 11\%-a teszi ezt örömmel, szemben az uniós átlaggal, ami eléri a 30\%-ot. Igen magas azok aránya (53\%) akik egyáltalán nem sportolnak és csak a válaszadók 9\%-a mondta azt, hogy rendszeresen sportol.

A 3. ábra adatait elemezve arra a következtetésre jutunk, hogy a serdülőkorú fiatalok 1/5e végez csak napi gyakorisággal rendszeres testmozgást. Ez az eredmény nagyon kedvezőtlen képet fest, de a teljes lakosság körében végzett kutatási eredmények, mely szerint a fiatalkorú- akhoz képest felnőttkorban többen mozognak már bizakodásra adhatnak okot. Azonban az a tény, hogy a lakosság több mint fele egyáltalán nem sportol, teljesen elfogadhatatlan.

A HBSC kutatás adatai elemezve megállapítható, hogy a serdülőkorú fiatalok esetében lényegesen magasabb a rendszeresen végzett, aktív testmozgás a fiúk körében. Az ő görbéjük szinte megegyezik az átlaggörbével, ugyanakkor a lányok görbéje a napi rendszerességgel végzett aktív testmozgás vonatkozásában évról-évre folyamatos emelkedést mutat, miközben a fiúk esetében 2018-ban visszaesett 21,1\%-ra (622 fó) és megközelíti a 2002-es adatokat, 18,3\% (500 fö) (NÉMETH et al., 2019).

\section{3. ÁBRA}

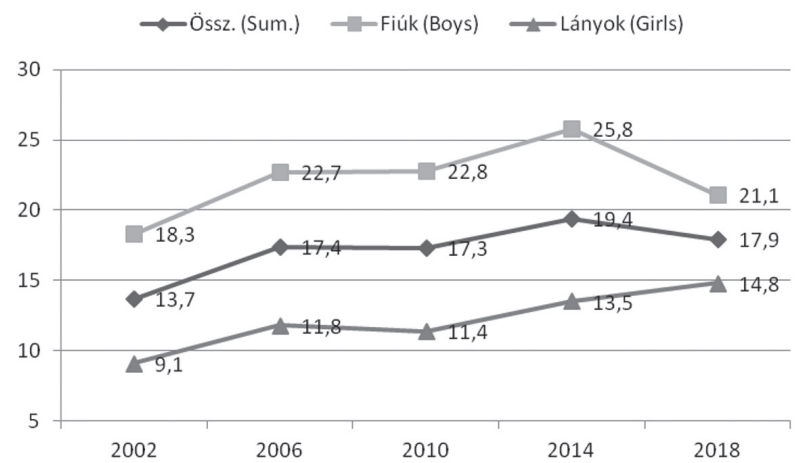

Naponta legalább 60 percet közepes intenzitással mozgó 11-17 éves magyar fiatalok arányának változása (The Change in the Proportion of 11-17-Year-Old Hungarian Young People Training for at Least 60 Minutes at Medium Intensity a Day)

Forrás (Source): Saját szerkesztés Németh et al., 2019 adatai alapján (Authors'own compilation based on data of Németh et al., 2019) 


\section{3•3. Kockázati magatartás - \\ Risk Behaviour}

A vizsgált korosztály körében a naponta dohányzók aránya 2002-tôl 2010-ig növekedett, különösen a fiúk körében, a lányok esetében viszont már kis mértékben ugyan, de 2006-hoz képest csökkenés figyelhető meg (4. ábra). A 2014. évi vizsgálati adatok markáns csökkenést mutatnak, míg 2010-ben a válaszadók 16,8\%a (1360 fó) dohányzott napi rendszerességgel, 2014-ra ez az arány lecsökkent 11,9\%-ra (732 fő). Viszont a nemek közötti különbség gyakorlatilag megszünt. A csökkenő tendencia a következő négy évben is jellemző volt a vizsgált korosztályra. 2018-ra a dohányzó fiatalok száma a 2010-es adatokhoz képest jelentősen csökkent. Míg 2010-ban a fiatalok 16,8\%-a (1360 fő) dohányzott napi gyakorisággal, 2018ban már csak a fiatalok 10,6\%-a (636 fó) (NÉMETH et al., 2019).
A WHO (Egészségügyi Világszervezet) és a CDC (Betegségmegelőzési és Járványvédelmi Központ) által hazánkban végzett kutatás adatai elemezve megállapíthatjuk, hogy az ezredfordulót követően a naponta dohányzók aránya 2013-ig nőtt. Ezzel szemben a 2016-os eredmények már csökkenést mutatnak, a korábbi 9,5\%-ról 6\%-ra csökkent naponta dohányzók aránya. A nemek aránya viszont jelentősen változott, oly módon, hogy a lányoknál lett magasabb (DEMJÉN et al., 2017).

A Nemzetközi Ifjúsági Dohányzásfelmérés reprezentatív vizsgálata is azt mutatja, hogy a fiatalok dohányzási szokásai változnak, mégpedig jó irányba. A 2008-ban és azóta rendszeres időközönként végzett kutatási adatok eredményei is bizakodásra adnak okot, mely szerint a napi rendszerességgel rágyújtó fiatalok aránya 2008 óta folyamatosan csökken (DEMJÉN et al., 2009).

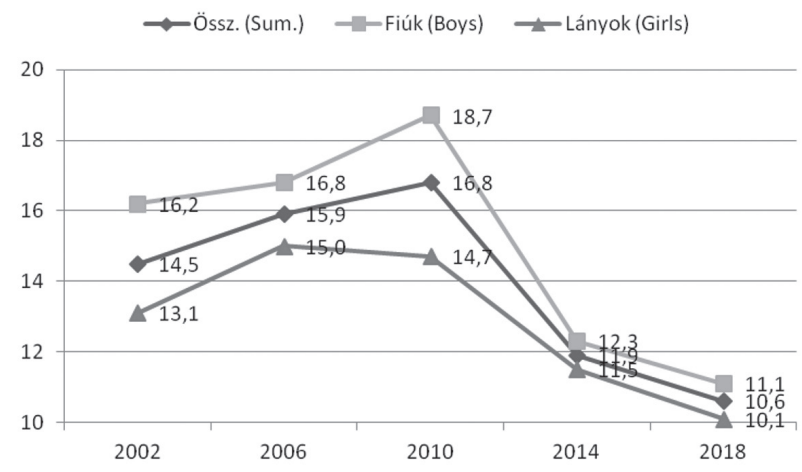

4. ÁBRA

A minden nap dohányzó 11-17 éves magyar fiatalok arányának változása

FIG. 4 (The Change in the Proportion of 11-17-Year-Old Hungarian Young People Smoking Daily) Forrás (Source): Saját szerkesztés Németh et al., 2019 adatai alapján (Authors'own compilation based on data of Németh et al., 2019)

Az 5. ábrát elemezve megállapíthatjuk, hogy az alkoholfogyasztás, mint kockázati tényező jelen van a 11-17 éves korosztály életében. 2010-ig folyamatos emelkedés figyelhető meg, mind a lányok, mind a fiúk esetében. Sőt a lányoknál az azt követő években is az emelkedés volt a jellemző egészen 2014-ig. Ebből adódóan a különbség a lányok és a fiúk között csökkent, bár mindig a fiúk értékei a magasabbak. 2014 óta viszont egyértelműen a csökkenés jellemző, különösen a fiúk esetében figyelhető ez meg a 2002-es adatokhoz 32,7 (893 fó) viszonyítva, míg a lányok esetében még mindig magasabb a 2018-as érték, 23,6\% (720 fó), mint a 2002-es 20,1\% (649 fó) (NÉMETH et al., 2019).

Általános iskolások alkoholfogyasztására elsősorban az alkalomszerű fogyasztás jellemző. A megkérdezettek 30\%-a nyilatkozott úgy, hogy 14 éves kora előtt már lerészegedett és az 5. ábra adatai alapján is látható, hogy magas azok aránya, akikkel mér legalább két alkalommal történt ez meg (ARNOLD, 2014).

ELEKES (2016) kutatási eredményei a HBSC kutatás eredményeivel összhangban azt 
mutatják, hogy 2015-ben jelentősen csökkent az alkoholfogyasztó serdülők aránya, viszont ez nagyobb mértékben figyelhető meg a fiúknál.

Szinte valamennyi hazai és régiós kutatás (BARABÁSNÉ, 2014; BOZSEK, 2010; ELE-
KES, 2016) eredményei azt mutatják, hogy az alkoholfogyasztás a vizsgált korosztályban jelen van, sőt nagyon gyakori problémák közé sorolható.

\section{5. ÁBRA}

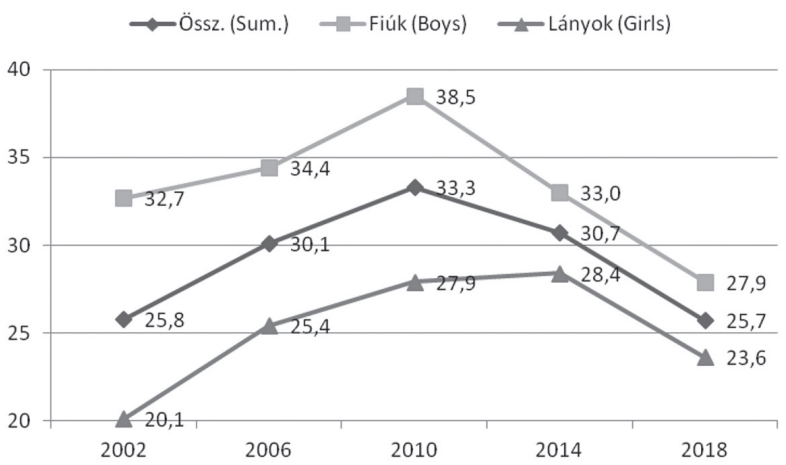

Az életükben már legalább két alkalommal lerészegedett 11-17 éves magyar fiatalok arányának változása (The Change in the Proportion of 11-17-Year-Old Hungarian Young People Drunken at Least Twice in Their Lifetime)

Forrás (Source): Saját szerkesztés Németh et al., 2019 adatai alapján (Authors'own compilation based on data of Németh et al., 2019)

\section{KÖVETKEZTETÉSEK ÉS}

\section{JAVASLATOK - CONCLUSIONS AND PROPOSALS}

Tanulmányunkban vizsgált mutatók változásait bemutató hazai kutatási eredményeket elemezve egyaránt tapasztaltunk kedvező és kedvezőtlen változásokat is.

Az adatokat tekintve egyértelmúen kedvezőnek tekinthetjük a cukortartalmú üdítőitalok fogyasztási gyakoriságának csökkenését, melyben szerepe lehet a cukormentes üdítőitalok megjelenésének. Továbbá örvendetes tény, hogy a napi rendszerességgel dohányzók aránya lényegesen csökkent, melyben szerepet játszhat, hogy 2011-ben került sor törvényi szinten a dohánytermékek értékesítésének szigorítására. Ezzel szemben kifejezetten kedvezőtlen a naponta gyümölcsöt fogyasztók számának csökkenése 2018-ra, különösen úgy, hogy 2014-ig fokozatosan emelkedett ez a szám és 2015 szeptember elsején lépett hatályba a közékeztetésre vonatkozó táplálkozás-egészségügyi előírásokról szóló 37/2014.(IV.30) EMMI rendelet, mely különös hangsúlyt fektet a friss gyümölcs és zöldség fogyasztásra. A fi- zikai aktivitás vizsgálata során a napi rendszerességgel sportoló lányok aránya fokozatosan emelkedett ezzel szemben a fiúk aránya 2014hez képest 2018-ra jelentősen visszaesett. Öszszességében örömteli, hogy többen mozogtak naponta legalább 60 percet 2018-ban mint 2002-ben, de még így is nagyon alacsony a közel 18\% (1075 fó) a vizsgált korosztályon belül. A lerészegedés, mint rizikómagatartás tekintetében 2002 és 2008 között a helyzet nem változott, szinte ugyanazon eredmény született. Viszont a lányok és a fiúk közötti különbség lényegesen lecsökkent már 2014-re. Az adatok azt mutatják, hogy hazánkban a serdülők körében az alkoholfogyasztás nagymértékben jelen van.

Úgy gondoljuk, hogy a legnagyobb problémát az emberek jelenlegi életmódjában a tudatos magatartás hiánya okozza. A legtöbben nincsenek tisztában az életmód egészségre gyakorolt hatásával. Hatékony programokkal kellene tudatosítani az emberekben az egészséges életmód egészségre gyakorolt jótékony hatását.

A szakemberek részéról fontos lenne, hogy az egészséges életmóddal kapcsolatosan minél szélesebb körben megvalósuló programokat hozzanak létre és ezeket meg is tudják valósíta- 
ni. Az Iskolai Egészségfejlesztés program célja a nevelési-oktatási intézményekben előre megadott szakmai követelményeknek megfelelően végzendő egészségfejlesztési terv megvalósítását és értékelését jelenti, melynek célja, hogy minden diák részesüljön egészségfejlesztési és prevenciós ismeretekben (OROSZI, 2019). Az EFOP 1.8.o-VEKOP-17-2017-00001 kiemelt projekt keretén belül a szakemberek a 7-18 éves korosztály egészségtudatosságának fejlesztésével kiemelten foglalkoztak. A korábbi kutatási eredményeket felhasználva szakmai tananyagot és módszertan dolgoztak ki 2019-ben. A tananyagot korosztályokra lebontva készítették el, mely a Nemzeti Alaptanterve is beilleszthető, kiemelt témaként foglalkozik a tananyag a mozgás fontosságával, a táplálkozással, a káros szenvedélyek mellőzésével és az egészséges jövőkép fontosságával (SETÉNYI, 2019). Fontos, hogy az egészséges életmód, a helyes táplálkozás és az aktív, rendszeres testmozgás az egészségfejlesztési stratégiákban kiemelt helyet kapjon. Az elért kutatási eredmények is azt igazolják, hogy vannak már megvalósított, folyamatban lévő programok, hiszen a vizsgált időszakban elért kutatási eredmények adataiban tapasztaltunk kedvező változásokat. De vannak olyan változók, melyek visszaesést, azaz kedvezőtlen változást mutatnak.

Első és legfontosabb lépésnek tartjuk az egyéni szemlélet megváltoztatására irányuló törekvéseket. Ebben kulcsfontosságú szerepe van a kommunikációnak valamint annak, hogy egy-egy program mindig a célcsoport sajátosságait figyelembe véve kerüljön megvalósításra. Fontos, hogy a programok könnyen átláthatóak, egyszerüek, közérthetőek legyenek. Sikerként könyvelhetjük el, hogy a teljes körü iskolai egészségfejlesztési program (TIE) 2012 óta jogszabályokban előírásként is szerepel a nemzeti köznevelésről szóló 2011. évi CXC. törvényben (SIMICH, 2019).

A szemlélet formálását véleményünk szerint már gyermekkorban el kell kezdeni. Tudatos egészségfejlesztési módszerrel kialakítható bennük az új életszemlélet, s ez által felnőttkorukra természetessé válik ez a fajta magatartás. A gyerekek szemlélete még kialakulóban van, formálható. A gyerekek, a fiatalok jelenlegi mintái meghatározzák felnőttkori életüket. Ezért tartjuk fontosnak, hogy a szemléletvál- toztatást minél fiatalabb korban kell elkezdeni. Jó irányvonalat kell a kezükbe adni, mellyel elkezdődhet egy folyamat.

Szakirodalmi kutatási munkánk során az volt a célunk, hogy a serdülőkori fiatalok egészségtudatos magatartásáról egy átfogó képet kapjunk az elmúlt közel 20 év eredményei alapján. A korábbi hazai kutatások adatait felhasználva, a kapott eredmények alapját képezik egy folyamatban lévő, konkrét primer kutatási munkának, melynek célja feltárni az általános iskola felső tagozatos diákok rendszeres testmozgáshoz való viszonyát és az egészséges életmóddal kapcsolatos gondolkodás módját. További célunk megvizsgálni, hogy a 11-14 éves korosztály mindennapjaiban hogyan van jelen az aktív, rendszeres testmozgás, valamint hogy milyen gyakorisággal sportolnak, illetve milyen összefüggés figyelhető meg a gyerekek egészségtudatos szemlélete és a sportolási szokásai között, valamint, hogy mennyire vannak tisztában a gyerekek az egészséges táplálkozás szerepével.

\section{5. ÖSSZEFOGLALÁs - SUMMARY}

Magyarországon az egészséges életmód tudatosítása és fontossága kiemelt szerepet kap az emberek mindennapjaiban, azonban az emberek tényleges egészségtudatos magatartása nem tekinthető megfelelőnek. A helytelen táplálkozás, a mozgásszegény életmód és a dohányzás valamint egyéb káros szenvedélyek még napjainkban is súlyos megbetegedésekhez és korai - elkerülhető - halálozáshoz vezetnek. Az elhízás és az ahhoz kapcsolódó összes betegség (magas vérnyomás, cukorbetegség, szív- és érrendszeri betegségek) népbetegségnek számítanak. Az egészséges életmód témakörnek egyre nagyobb figyelmet szentelnek hazánkban, de a gyakorlatban még mindig nem tökéletes a megvalósítása, melyben fontos szerepe van az egyéneknek és a szakembereknek is.

Tanulmányunkban a serdülőkori egészségmagatartás három kérdéskörével foglalkoztunk dokumentumelemzés keretén belül. A korábbi hazai kutatási eredmények alapján megállapítható, hogy az elmúlt közel 20 év során a vizsgált korosztály életmódjában és egészséghez füződő viszonyában egyaránt megfigyelhetők 
kedvező és kedvezőtlen változások.

A kedvező adatok rávilágítanak arra, hogy elindult már egy folyamat, de még a hosszú út elején járunk. A szakemberekre nagyon sok feladat vár, hogy egy egészséges társadalom alakuljon ki Magyarországon.

$\mathrm{Az}$ egészséges életmódra, az egészséges táplálkozásra nevelést és a testmozgást, a sport szeretetét már a legfiatalabb korban el kell kezdeni. Kiemelkedő jelentőséggel bír, hogy felnőjön egy olyan új generáció, melynek az egészséges életmód, az egészséges táplálkozás a rendszeres testmozgás a lételeme. Ennek megvalósításához támogató környezetre, az oktatási intézményekkel közösen együttműködő családi háttérre van szükség.

\section{KöSZÖNETNYILVÁNÍTÁS -}

\section{ACKNOWLEDGEMENT}

A publikáció elkészítését az EFOP-3.6.1-162016-00022 számú, Debrecen Venture Catapult Program címü projekt támogatta. A projekt az Európai Unió támogatásával, az Európai Szociális Alap társfinanszírozásával valósult meg.

\section{IRODALOMJEGYZÉK - REFERENCES}

Anderson, P. M. - Butcher, K. E.: Childhood Obesity: Trends and Potential Causes. The Future of Children. Childhood Obesity. 2006. 16 (1) 19-45. DOI: https:// doi.org/10.1353/foc.2006.0001

Arnold, P.: Alkoholfogyasztási szokások. In: Német, Á - Költő, A. (szerk.): Egészség és egészségmagatartás iskoláskorban. Budapest, Nemzeti Egészségfejlesztési Intézet, 2014. 58-72.

Barabásné, K. D.: Vidéken élő fiatalok szenvedélyei: az alkoholfogyasztás társadalmi, demográfiai háttere. Agrártudományi Közlemények. Debrecen, 2014. 6o 81-84.
Bíró, L.: A 11-18 éves fiatalok anthropometriai adatainak értékelése. In: Antal, E. - Pillig, R. (szerk.): A magyar gyermekek és fiatalok életmódja. Fehér Könyv a Tét Platform Egyesület kutatásainak adatai alapján, 2018. 43-44.

Bíró, M. - Pucsok, J. M. - Hidvégi, P. Tatár, A. - Lenténé, P. A.: Az Északalföldi régió lakosságának egészségi állapota - a mozgás potenciálja. In: Balogh, L. (szerk.): Fókuszban az egészség. Debreceni Egyetem Sporttudományi Koordinációs Intézet, Debrecen, 2018. 61-72.

Bozsek, N.: Merre tartasz ifjúság? Család, gyermek, ifjúság. 2010. (1) 36-45.

Demjén, T. - Kiss, J. - Bóti, E. Lárik, E. - Papp, N. - Kovács, D.: Nemzetközi Ifjúsági Dohányzásfelmérés. Országos Egészségfejlesztési Intézet, Budapest, 2009. URL: https://mek.oszk. hu/07900/07959/07959.pdf (Letöltés dátuma: 2020.09.10.)

Demjén, T. - Kiss, J. - Viski, D.: Egészségügyi Világszervezet Dohányzásellenőrzési Keretegyezmény: magyar országjelentések 2017. Egészségfejlesztés. 2017. 58 (1) 60-67. DOI: http://dx.doi. org/10.24365/ef.v58i1.144.

Elekes, Zs.: Európai iskolavizsgálat az alkohol- és egyéb drogfogyasztási szokásokról - 2015. Magyarországi eredmények. Budapest, Budapesti Corvinus Egyetem Társadalomtudományi és Nemzetközi Kapcsolatok Kar Szociológiai és Társadalompolitikai Intézet, 2016.

Eurobarometer: Sport and Physical Activity Report. 2017. URL: https:// data.europa.eu/euodp/en/data/dataset/ S2164_88_4_472_ENG (Letöltés dátuma: 2020.02.23.)

Falus, A.: Sokszínű egészségtudatosság Értsd, csináld, szeresd! SpringMed Kiadó, Budapest, 2015.

Füge, K.: A testtömegindex és az egészséges táplálkozáshoz kapcsolódó attitűdök. Új diéta. 2015. 24 (4) 2-4. 
Fülöp, N. - Szakály, Z.: Fiatalok táplálkozási szokásai, egészségmagatartása. Élelmiszer, Táplálkozás és Marketing. 2008. 5 (1) 8186.

Gyulavári, T. - Malota, E. - Bogáromi, E.: Percepció, attitűd és követett magatartás az egészséges táplálkozás terén - egy hazai empirikus felmérés eredményei In: Józsa, L. - Korcsmáros, E. - Seres, H. E. (szerk.): A hatékony marketing - EMOK 2018 Nemzetközi Tudományos Konferencia, Budapest, 848-860.

Hídvégi, P. - Kopkáné, P. J. - Müller, A.: Az egészséges életmód. Eszterházy Károly Főiskola, Eger, 2015.

Holczer, A. - Kiss, V.: A szülői egészségtudatosság és az étkezési preferenciáik vizsgálata a gyermekkori elhízás tükrében. Táplálkozásmarketing. 2019. 6 (2) 27-38. DOI: https://doi. org/10.20494/tm/6/2/3

Janssen, I. - Leblanc, A. G.: Systematic Review of the Health Benefits of Physical Activity and Fitness is School-aged Children and Youth. The International Journal of Behavioral Nutrition and Physical Activity. 2010. 7 40. DOI: https:// doi.org/10.1201/b18227-14

Járomi, É. - Szilágyi, K. - Vitrai, J.: Egészséges életmóddal kapcsolatos kutatások a hazai iskolákban. Egészségfejlesztés. 2016. 57 (1) 2-40.

KSH: Egészségi állapot és egészségmagatartás, 2016-2017. Statisztikai Tükör. 2018. július 23. URL: http://www.ksh.hu/docs/hun/ xftp/stattukor/egeszsegallapot1617.pdf (Letöltés dátuma: 2020.02.15.)

Lenténé, P. A. - Hídvégi, P. - Tatár, A. Pucsok, J. M. - Bíró, M.: A rekreációs turizmus lehetőségei Magyarországon az Észak-alföldi régióban. In: Balogh, L. (szerk.): Fókuszban az egészség. Debreceni Egyetem Sporttudományi Koordinációs Intézet, Debrecen, 2018. 19-30., 12.

Lőrinczi, K.: Az egészségtudatos táplálkozási magatartás hatása az üdítőital fogyasztásra. Debreceni Egyetem Agrárés Gazdálkodástudományok Centruma, Debrecen, 2010. 54-55.
Martos, É.: A fizikai aktivitás szerepe az elhízás megelőzésében gyermek és felnőttkorban. Akadémia Kiadó, Budapest, 2012.

Miles, L.: Physical Activity and Health. Nutrition Bulletion. 2007. 32 (4) 314-363. DOI: https://doi. org/10.5040/9781492596905.part-003

Németh, Á. - Költő, A.: Egészség és egészségmagatartás

Iskoláskorban. ELTE Pedagógiai és Pszichológiai Kar, Pszichológiai Intézet, Budapest, 2016.

Német, Á. - Horváth, Zs. - Várnai, N.: Egészségmagatartás a serdülőkorban - Mi történt az ezredforduló után? Educatio. 2019. 28 (3) 473-494. ELTE Pedagógiai és Pszichológiai Kar, Pszichológiai Intézet, Budapest, DOI: https://doi. org/10.1556/2063.28.2019.3.3

Oroszi, B.: Mitől lesz menő az iskolai egészségfejlesztés? - Egészségtudatosság fejlesztése a 7-18 éves korosztályrészére -Modellprogram, Budapest, 2019. URL: https://efop18o.antsz.hu/ (Letöltés dátuma: 2020.11.12.)

Setényi, J.: Hogyan tanítható az egészségnevelés színesen? - Egészségtudatosság fejlesztése a 7-18 éves korosztályrészére - Modellprogram, Budapest, 2019. URL: https://efop180. antsz.hu/ (Letöltés dátuma: 2020.11.12.)

Simich, R.: Új utak, új célok? Egészségtudatosság fejlesztése a 7-18 éves korosztályrészére - Modellprogram, Budapest, 2019. URL: https://efop180. antsz.hu/ (Letöltés dátuma: 2020.11.12.)

Strong, W. B. - Malina, R. M. - Blimkie, C. J. R. - Daniels, S. R. - Dishman, R. K. - Guitin, B. - Hergenroeder, A. C. - Must, A. - Nixon, P. A. - Pivarnik, J. M. - Rowland, T. - Trost, S. Trudeau, F.: Evidence Based Physical Activity for School-age Youth. The Journal of Pediatrics. 2005. 146 (6) 732-737. URL: https://doi.org/10.1016/soo843954(08)70234-3

WHO: The World Health Report 2003 Shaping The Future. URL: https://www. who.int/whr/2003/en/ (Letöltés dátuma: 2020.09.18.) 